\title{
High concentrations of pyridoxal stimulate the expression of IGFBP1 in HepG2 cells through upregulation of the ERK/c-Jun pathway
}

\author{
PEIPEI ZHANG, SOFYA SUIDASARI, TOMOMI HASEGAWA, NORIYUKI YANAKA and NORIHISA KATO
}

Graduate School of Biosphere Science, Hiroshima University, Higashi-Hiroshima, Hiroshima 739-8528, Japan

Received April 6, 2013; Accepted August 8, 2013

DOI: $10.3892 / \mathrm{mmr} .2013 .1629$

\begin{abstract}
Increasing evidence suggests that dietary vitamin B6 is linked to the prevention of cancer and cardiovascular disease. However, the molecular mechanisms involved in this process are not yet understood. Preliminary results in the current study indicated, following DNA microarray analysis and quantitative PCR, that insulin-like growth factor-binding protein 1 (IGFBP1) mRNA is upregulated in HT29 colon carcinoma cells exposed to pyridoxal (PL, $500 \mu \mathrm{M}$ ). IGFBP1 is secreted from the liver and is hypothesized to exert a protective role in the development of cancer and cardiovascular disease. Thus, further experiments were performed to investigate the effect of PL on the expression of IGFBP1 in HepG2 hepatocellular carcinoma cells. The addition of PL $(500 \mu \mathrm{M})$ markedly increased the expression of IGFBP1 mRNA in HepG2 cells at 6,12 and $24 \mathrm{~h}(\mathrm{P}<0.01)$, whereas other vitamers $(500 \mu \mathrm{M})$, including pyridoxal 5'-phosphate (PLP), pyridoxine (PN) and pyridoxamine (PM), caused no such effect. The expression of the IGFBP1 protein in the cell lysate and culture medium was elevated in the presence of PL. PL elevated expression of the active form of ERK1 protein, p-ERK1, and the p-c-Jun protein, a downstream factor of
\end{abstract}

Correspondence to: Professor Norihisha Kato, Graduate School of Biosphere Science, Hiroshima University, 1-4-4 Kagamiyama, Higashi-Hiroshima, Hiroshima 739-8528, Japan

E-mail: nkato@hiroshima-u.ac.jp

Abbreviations: iNOS, inducible nitric oxide synthase; COX-2, cyclooxygenase-2; IGFBP1, insulin-like growth factor-binding protein 1; NF- $\mathrm{B}$, nuclear factor- $\kappa \mathrm{B}$; LPS, lipopolysaccharide; IGFs, insulin growth factors; IGFBP3, insulin-like growth factor-binding protein 3; PL, pyridoxal; PN, pyridoxine; PM, pyridoxamine; PLP, pyridoxal 5'-phosphate; DMEM, Dulbecco modified Eagle's medium; MTT,3-(4,5-dimethylthiazol-2-yl)-2,5-diphenyltetrazolium bromide; LDH, lactate dehydrogenase; DMSO, dimethyl sulfoxide; SDS-PAGE, sodium dodecyl sulphate-polyacrylamide gel electrophoresis; MAPK, mitogen-activated protein kinase; PVDF, polyvinylidene difluoride; PD, PD98059; CHX, cycloheximide

Key words: pyridoxal, IGFBP1, HepG2 cells, cancer, cardiovascular disease
ERK. Furthermore, IGFBP1 expression, elevated by PL, was suppressed by PD98059, an ERK inhibitor. Higher expression of IGFBP1 protein by PL was suppressed by cycloheximide. These results suggest that PL may induce the expression of IGFBP1 in hepatoma cells via a mechanism involving the ERK/c-Jun pathway.

\section{Introduction}

There is increasing epidemiological evidence implicating vitamin B6 as a protective factor against colon cancer (1-4). Consistent with these previous results, the current study observed that dietary vitamin B6 intake, from a supplemental vitamin B6 diet to a low vitamin B6 diet, caused a marked reduction in colon tumorigenesis in mice exposed to azoxymethane (5). Our animal studies suggest that the anti-colon tumor effect of dietary vitamin B6 is partially ascribed to lowering colon cell proliferation, oxidative stress, inflammation and epithelium cell damage (5-8). Furthermore, we observed that vitamin B6 inhibited lipopolysaccharide (LPS)-induced expression of inducible nitric oxide synthase (iNOS) and cyclooxygenase-2 (COX-2) in mouse macrophage RAW264.7 cells via suppression of nuclear factor- $\kappa \mathrm{B}(\mathrm{NF}-\kappa \mathrm{B})$ activation (9). In addition, dietary vitamin B6 inhibited iNOS activity in the liver of rats exposed to LPS (9). Notably, vitamin B6 has been observed to inhibit DNA and RNA polymerase (10-12), topoisomerase-IB and angiogenesis $(13,14)$. However, the molecular mechanisms involved in the antitumor effect of vitamin B6 are not yet clearly understood.

According to preliminary experimental results in the current study, which used DNA microarray analysis, a number of genes were upregulated by pyridoxal (PL; $500 \mu \mathrm{M})$ in human colon cancer cells (HT29). Insulin-like growth factor-binding protein 1 (IGFBP1) was one of these upregulated genes in HT29 cells, confirmed by quantitative PCR. IGFBP1 is primarily produced and secreted from the liver (15) and binds to insulin growth factors (IGFs), modulating their actions (15). Previous studies have suggested that IGFBP1 may be a tumor suppressor (16-19). Low serum IGFBP1 levels are associated with a number of chronic diseases, including colon cancer, cardiovascular disease and diabetes (20-22). A previous study showed that increased circulating IGFBP1 levels improve insulin sensitivity, lower blood pressure and protect against atherosclerosis (22). IGFBP1 is rapidly induced 
during liver regeneration and is implicated in the maintenance of hepatocyte differentiation and metabolism $(23,24)$. The liver is a central organ involved in regulating vitamin B6 metabolism (25). In addition, Nakari et al (26) demonstrated that a high dose of pyridoxine (PN; $10 \mathrm{mM}$ ) induced the expression of the insulin-like growth factor-binding protein 3 (IGFBP3) in human breast adenocarcinoma MCF-7 cells. Therefore, the objective of the current study was to explore the effect of vitamin B6 on the expression of IGFBP1 in human hepatoma HepG2 cells.

\section{Materials and methods}

Materials. PL hydrochloride, PN hydrochloride and pyridoxal 5'-phosphate (PLP) were obtained from Nacalai Tesque (Kyoto, Japan) and pyridoxamine (PM) dihydrochloride was obtained from Calbiochem (La Jolla,CA, USA). Human colorectal cancer HT29 cells and human hepatoma HepG2 cells were purchased from the Health Science Research Resources Bank (Osaka, Japan) and the Japan Health Science Foundation (Tokyo, Japan), respectively. Dulbecco's modified Eagle's medium (DMEM) was purchased from Sigma-Aldrich (St. Louis, MO, USA). Antibodies specific for IGFBP1 and p-c-Jun were products of Santa Cruz Biotechnology, Inc. (Santa Cruz, CA, USA). An antibody against p-ERK1/2 was obtained from Cell Signaling Technology Inc. (Danvers, MA, USA). Tubulin antibody was obtained from Harlan Sera-Lab (Leicestershire, UK). 3-(4,5-Dimethylthiazol-2-yl)-2,5-diphenyltetrazolium bromide (MTT) was purchased from Sigma-Aldrich. Dimethyl sufoxide (DMSO) was obtained from Nacalai Tesque. PD98059 (ERK inhibitor) was purchased from Wako Pure Chemical Industries (Osaka, Japan). Cycloheximide (protein synthesis inhibitor) was also purchased from Wako Pure Chemical Industries.

Cell culture and treatment. HT29 and HepG2 cells were maintained in DMEM supplemented with $10 \%$ fetal calf serum, $100 \mathrm{U} / \mathrm{ml}$ penicillin and $100 \mathrm{mg} / \mathrm{ml}$ streptomycin at $37^{\circ} \mathrm{C}$ in $5 \% \mathrm{CO}_{2}$. PL, PN, PM or PLP were dissolved directly in culture medium and filtered through a Millex-HV $0.45-\mu \mathrm{m}$ syringe filter (Millipore, Billerica, MA, USA). PD98059 was dissolved in DMSO and added directly to the culture medium. DMSO, instead of the inhibitor, was added to the other groups.

LDH assay. Cytotoxicity of PL in HepG2 cells was determined using a lactate dehydrogenase (LDH) assay kit

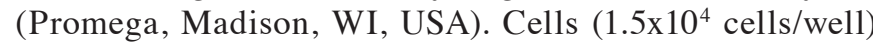
were seeded in a 96-well plate with $120 \mu \mathrm{l}$ culture medium. Following $24 \mathrm{~h}$, cells were treated with or without PL at a concentration of $500 \mu \mathrm{M}$ for 6,12 or $24 \mathrm{~h}$. A total amount of $100 \mu \mathrm{l}$ of supernatant for each well was transferred to a new 96-well plate and $100 \mu \mathrm{l}$ of reconstituted substrate mix was added to each well and the plates were maintained at room temperature for $60 \mathrm{~min}$. Absorbance was recorded at $490 \mathrm{~nm}$ with an ELNX 96 reader (TFB, Tokyo, Japan). Each experiment was repeated eight times.

MTT assay. Cell culture medium suspensions (3,000 cells/100 $\mu \mathrm{l})$ were plated into 96-well plates. Following $24 \mathrm{~h}$ incubation, $100 \mu \mathrm{l}$ culture medium with or without PL
(500 $\mu \mathrm{M})$ was added to the wells and incubated for $6,12,24$ or $48 \mathrm{~h}$. At the end of the incubation, $20 \mu 10.5 \%$ MTT solution was added to each well. Plates were returned to the incubator for a period of $4 \mathrm{~h}$. Absorbance was read on a spectrophotometer with an ELNX 96 reader at $550 \mathrm{~nm}$. Each experiment was repeated eight times.

mRNA analysis. Total RNA from HT29 or HepG2 cells was isolated using TRIzol ${ }^{\mathrm{TM}}$ (Invitrogen Life Technologies, Carlsbad, CA, USA). Total RNA (1 $\mu \mathrm{g})$ was reverse transcribed using the First Strand cDNA Synthesis kit (Toyobo, Osaka, Japan) according to the manufacturer's instructions. Quantitative PCR was performed with a StepOne ${ }^{\mathrm{TM}}$ Real-Time PCR System (Applied Biosystems, Carlsbad, CA, USA) using Thunderbird SYBR qPCR Mix (Toyobo). The primer sets for IGFBP1 and GADPH were purchased from Greiner Bio-One (Tokyo, Japan) and were as follows: IGFBP1, 5'-GCCAAACTGCAA CAAGAATG-3' and 5'-ATCCTCTTCCCATTCCAAG-3'; and GADPH, 5'-CAATGACCCCTTCATTGACC-3' and 5'-TGG AAGATGGTGATGGGATT-3'. The cycling parameters were as follows: Initial step at $90^{\circ} \mathrm{C}$ for $10 \mathrm{sec}$, followed by 40 cycles of $90^{\circ} \mathrm{C}$ for $5 \mathrm{sec}, 60^{\circ} \mathrm{C}$ for $10 \mathrm{sec}$ and $72^{\circ} \mathrm{C}$ for $10 \mathrm{sec}$. Relative gene expression levels were calculated using the $2^{-\Delta \Delta \mathrm{Ct}}$ method normalizing to GAPDH expression levels and fold differences in expression were calculated relative to control samples.

Western blot analysis. Western blot analysis experiments for IGFBP1 detection were performed using HepG2 cell lysate and culture medium. Cells were grown to $70 \%$ confluency in a 6-well plate. Following PL treatment, cells were washed twice with PBS and lysed in RIPA buffer $[20 \mathrm{mM}$ Tris- $\mathrm{HCl}$ (pH 7.4), $150 \mathrm{mM} \mathrm{NaCl}, 1 \mathrm{mM} \mathrm{MgCl}$ and $\left.1 \mathrm{mM} \mathrm{CaCl}_{2}\right]$ with $1 \%$ Triton $\mathrm{X}-100$. Cell lysate was centrifuged at $12,000 \mathrm{x}$ g for $10 \mathrm{~min}$ to pellet debris. Total protein samples were removed and assayed for protein content using a Bio-Rad Protein Assay kit (Bio-Rad, Hertfordshire, UK). Sodium dodecyl sulphate-polyacrylamide gel electrophoresis (SDS-PAGE) sample buffer was added to the protein pellets and samples were boiled for $3 \mathrm{~min}$ at $95^{\circ} \mathrm{C}$. Samples were loaded $(10 \mu \mathrm{g}$ of total protein for cell lysate) and electrophoretically separated on $10 \%$ polyacrylamide gels and transferred to polyvinylidene difluoride (PVDF) membranes. Western blot analysis was performed to standard instructions and proteins were visualized using the following primary antibodies: IGFBP1 (rabbit polyclonal antibody; 1:1,000), p-ERK1/2 (rabbit polyclonal antibody; 1:1,000), p-c-Jun (mouse monoclonal antibody; 1:1,000) and tubulin (rat monoclonal antibody; $1: 1,000)$.

To detect IGFBP1 in the culture medium, culture medium (1 ml) was collected and centrifuged at $12,000 \mathrm{x} \mathrm{g}$ for $10 \mathrm{~min}$. A total of $100 \mu \mathrm{l}$ of supernatant was added to $30 \mu \mathrm{l}$ SDS-PAGE sample buffer and boiled for $3 \mathrm{~min}$ at $95^{\circ} \mathrm{C}$. Each sample $(10 \mu \mathrm{l})$ was loaded for western blot analysis.

Statistical analysis. Data are presented as the mean \pm SE. Differences among the average means of treatment groups were analyzed using a one-way ANOVA and $\mathrm{P}<0.05$ was considered to indicate a statistically significant difference, as determined by Scheffe's multiple-range test. For experiments 
A
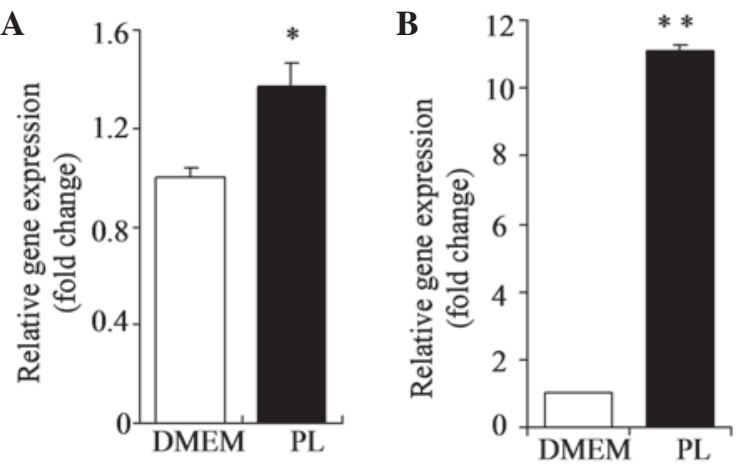

C

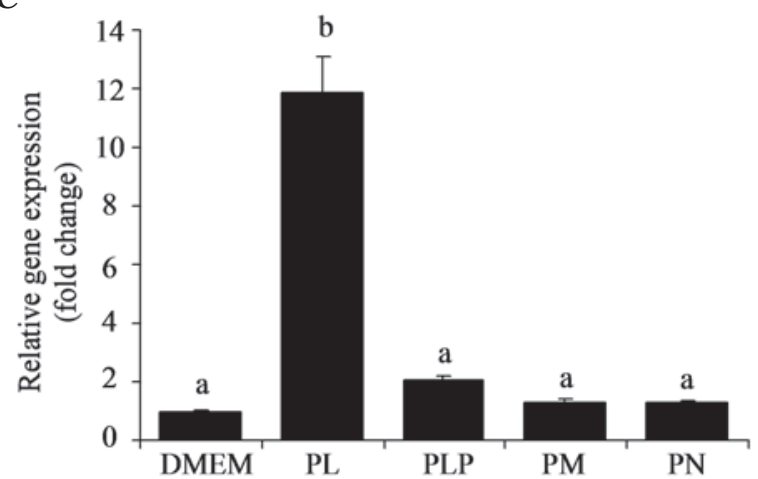

Figure 1. Stimulation of expression of IGFBP1 mRNA by PL in HT29 and HepG2 cells. (A) HT29 or (B) HepG2 cells were incubated in presence or absence of PL $(500 \mu \mathrm{M})$ over $24 \mathrm{~h}$. (C) HepG2 cells were incubated with various vitamers (PL, PLP, PM or PN) at a concentration of $500 \mu \mathrm{M}$ over $24 \mathrm{~h}$. IGFBP1 mRNA levels were determined by quantitative PCR. Cells cultured with medium (DMEM with $10 \%$ fetal calf serum, 100 units/ml penicillin and $100 \mathrm{mg} / \mathrm{ml}$ streptomycin) were used as control. Values are presented as the mean $\pm \mathrm{SE}(\mathrm{n}=4)$. ${ }^{*} \mathrm{P}<0.05$ and ${ }^{* *} \mathrm{P}<0.01$, vs. relative control. Groups with different letters are significantly different from each other $(\mathrm{P}<0.05)$. IGFBP1, insulin-like growth factor-binding protein 1; PL, pyridoxal; PLP, pyridoxal 5'-phosphate; PM, pyridoxamine ; PN, pyridoxine; DMEM, Dulbecco's modified Eagle's medium.

which included only two groups, a Student's t-test was used and the statistical difference was set at $\mathrm{P}<0.05$.

\section{Results}

$P L$ stimulates expression of IGFBPI $m R N A$. According to DNA microarray analysis, IGFBP1 was upregulated in HT29 cells exposed to PL (500 $\mu \mathrm{M})$. Stimulation of IGFBP1 by PL in HT29 cells was confirmed by quantitative PCR (Fig. 1A). HepG2 cells were incubated in the presence or absence of PL $(500 \mu \mathrm{M})$ for $24 \mathrm{~h}$ and IGFBP1 mRNA levels were determined by quantitative PCR. As shown in Fig. 1B, IGFBP1 mRNA levels were markedly elevated by $\mathrm{PL}$ in HepG2 cells $(\mathrm{P}<0.01)$. The effects of B6 vitamers $(500 \mu \mathrm{M})$, including PL, PM, PN and PLP, on the expression of IGFBP1 mRNA levels were analyzed (Fig. 1C). The results show that PL has a marked stimulation effect $(\mathrm{P}<0.05)$; however, other $\mathrm{B} 6$ vitamers did not exhibit the same effect.

PL stimulates IGFBPI expression in a time- and dose-dependent manner. The effects of various concentrations of PL on the expression of IGFBP1 mRNA were investigated. Following

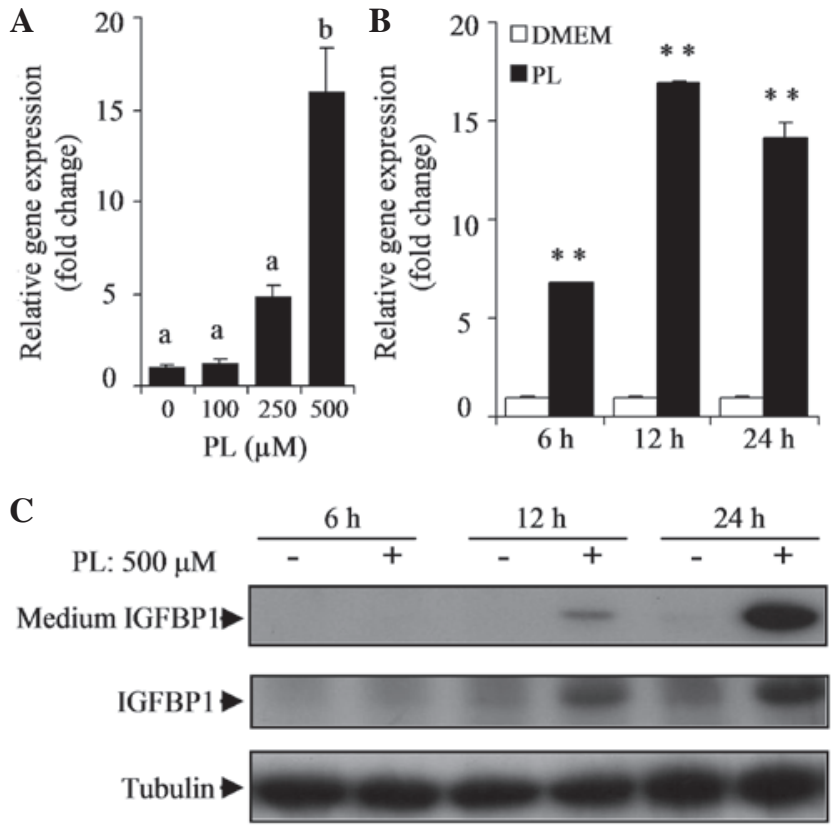

Figure 2. PL induced the expression of IGFBP1 in a time- and dose-dependent manner in HepG2 cells. (A) HepG2 cells were incubated with PL at various concentrations $(0,100,250$ or $500 \mu \mathrm{M})$ over 24 h. (B) HepG2 cells were incubated with PL at a concentration of $500 \mu \mathrm{M}$ for the indicated times $(6,12$ or 24 h). IGFBP1 mRNA levels were determined by quantitative PCR. Results are presented as the mean $\pm \operatorname{SE}(n=4)$. Groups with different letters are significantly different from each other $(\mathrm{P}<0.05)$. ${ }^{* *} \mathrm{P}<0.01$, vs. relative control. (C) Time-dependent stimulation of IGFBP1 protein expression by PL $(500 \mu \mathrm{M})$ was analyzed by western blot analysis. PL, pyridoxal; IGFBP1, insulin-like growth factor-binding protein 1.

$24 \mathrm{~h}$ incubation of HepG2 cells with varying concentrations of PL (100, 250 or $500 \mu \mathrm{M})$, IGFBP1 mRNA levels were elevated in a dose-dependent manner (Fig. 2A). At a concentration of $500 \mu \mathrm{M}$, PL markedly stimulated the expression of IGFBP1 mRNA levels in HepG2 cells $(\mathrm{P}<0.05)$. To examine the time-dependent effect of PL, HepG2 cells were cultured with or without PL (500 mM) for 6, 12 or $24 \mathrm{~h}$. The results showed that treatment with PL increased IGFBP1 mRNA levels in a time-dependent manner $(\mathrm{P}<0.01$; Fig. $2 \mathrm{~B})$. The expression of IGFBP1 protein in the cell lysate and culture medium increased in a time-dependent manner (Fig. 2C).

PL affects cell growth of HepG2 without showing cytotoxicity. The current cell culture studies were conducted with a supraphysiological dose of PL $(500 \mathrm{mM})$, thus the cytotoxicity of PL was examined at this dose. An LDH assay was performed to examine the cytotoxicity of PL $(500 \mathrm{mM})$ for various incubation times $(6,12$ or $24 \mathrm{~h})$. The results show that PL, at a concentration of $500 \mathrm{mM}$, caused no cytotoxicity to HepG2 cells over $24 \mathrm{~h}$ (Fig. 3A). In addition, the effect of PL on cell growth was examined with an MTT assay. HepG2 cells were incubated with PL (500 mM) for $6,12,24$ or $48 \mathrm{~h}$. PL significantly elevated cell growth over $12 \mathrm{~h}(\mathrm{P}<0.01$; Fig. 3B), while PL significantly suppressed cell growth over 24 and $48 \mathrm{~h}(\mathrm{P}<0.01)$. Thus, the induction of IGFBP1 by PL appears to begin prior to alteration in cell growth.

$P L$ activates the ERK pathway responsible for the stimulation of IGFBPI. Multiple mitogen-activated protein kinase 
A

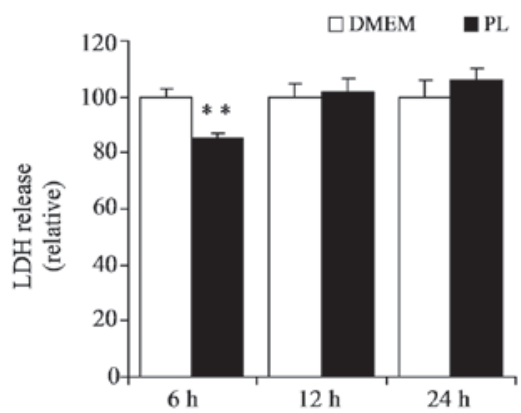

B

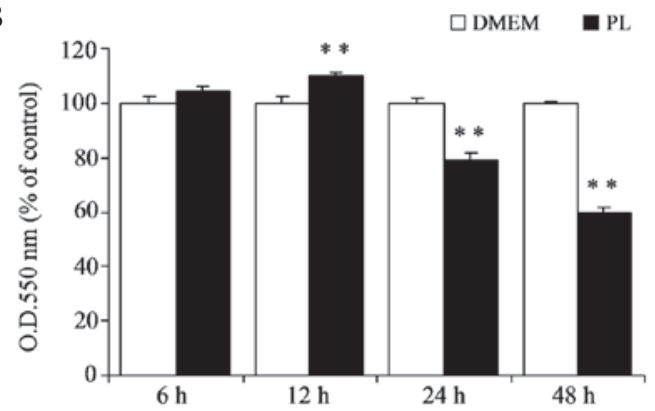

Figure 3. LDH and MTT assays in HepG2 cells exposed to PL. HepG2 cells were exposed to PL ( $500 \mu \mathrm{M}$ ) for various times (6, 12 or $24 \mathrm{~h}$ ). (A) Cytotoxicity was determined by measuring the amount of LDH released from the cells into the culture medium. Cultured cells $\left(3 \times 10^{3}\right.$ cells/well) were exposed to the medium with or without PL $(500 \mu \mathrm{M})$ over $6,12,24$ or $48 \mathrm{~h}$. (B) Cell growth was determined by the MTT assay. Cells cultured with medium (DMEM with $10 \%$ fetal calf serum, $100 \mathrm{U} / \mathrm{ml}$ penicillin and $100 \mathrm{mg} / \mathrm{ml}$ streptomycin) were used as control. The data are presented as the mean $\pm \mathrm{SE}(\mathrm{n}=8)$. ${ }^{* *} \mathrm{P}<0.01$, vs. relative control. LDH, lactate dehydrogenase; MTT, 3-(4,5-Dimethylthiazol-2-yl)-2,5-diphenyltetrazolium bromide; PL, pyridoxal.

A

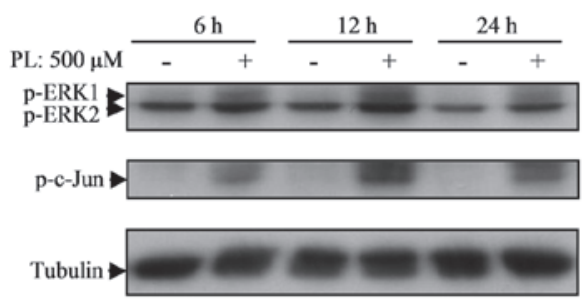

D

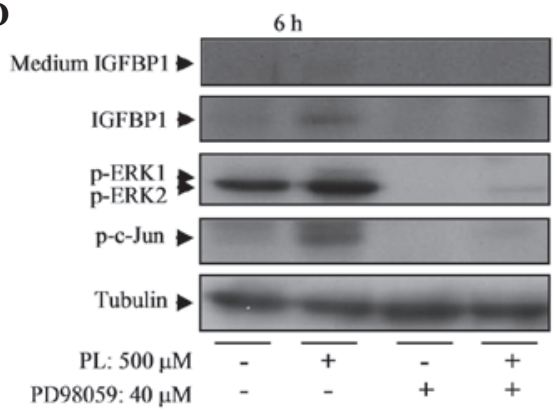

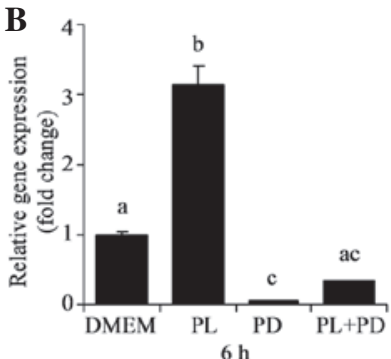

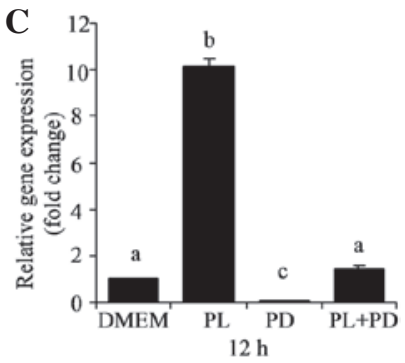
$\mathbf{E}$

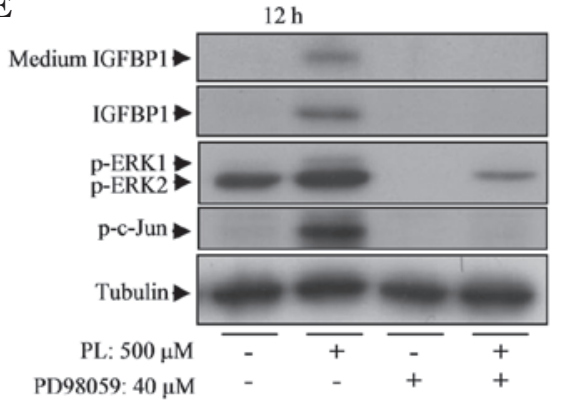

Figure 4. Activation of ERK pathway and stimulated expression of IGFBP1 by PL were blocked by ERK inhibitor in HepG2 cells. (A) HepG2 cells were incubated with PL at a concentration of $500 \mathrm{mM}$ for 6, 12 or $24 \mathrm{~h}$. Expression of p-ERK and p-c-Jun proteins was analyzed by western blot analysis. HepG2 cells were treated with PL (500 mM), PD98059 (PD, ERK inhibitor, 40 mM) or PL (500 mM) + PD98059 (PD, 40 mM) for (B) 6 or (C) 12 h. Cells incubated with culture medium were used as controls. IGFBP1 mRNA levels were analyzed by quantitative PCR. Cells cultured with medium (DMEM with $10 \%$ fetal calf serum, $100 \mathrm{U} / \mathrm{ml}$ penicillin and $100 \mathrm{mg} / \mathrm{ml}$ streptomycin) were used as control. Values are presented as the mean $\pm \mathrm{SE}$ ( $\mathrm{n}=4$ ). Groups with different letters are significantly different from each other $(\mathrm{P}<0.05)$. IGFBP1 protein level was analyzed by western blotting for $(\mathrm{D}) 6$ or $(\mathrm{E}) 12 \mathrm{~h}$. IGFB1, insulin-like growth factor-binding protein 1; PL, pyridoxal; DMEM, Dulbecco's modified Eagle's medium.

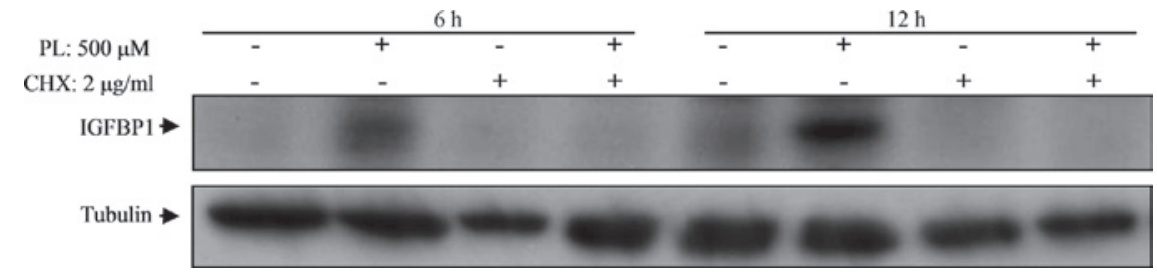

Figure 5. Effect of inhibitor of protein synthesis on the expression of IGFBP1 protein in HepG2 cells exposed to PL. HepG2 cells were cultured with CHX (protein synthesis inhibitor; $2 \mu \mathrm{g} / \mathrm{ml})$ with or without PL $(500 \mathrm{mM})$ for 6 or $12 \mathrm{~h}$. IGFBP1 protein level was analyzed by western blot analysis. IGFBP1, insulin-like growth factor-binding protein 1; PL, pyridoxal; CHX, cycloheximide.

(MAPK) pathways are reportedly involved in the stimulation of IGFBP1 (27-29). Therefore, in the current study, the protein expression of ERK, p-ERK, p-JNK and p-c-Jun (downstream factor of ERK and JNK) was examined in HepG2 cells treated with or without PL over 6, 12 or $24 \mathrm{~h}$. The results indicate that PL elevated p-ERK1 and p-c-Jun proteins significantly at 6 and 
$12 \mathrm{~h}$ (Fig. 4A). Total ERK and p-JNK expression were not affected by PL (data not shown).

Activation of the ERK pathway by PL led to the hypothesis that the ERK pathway is involved in the stimulation of IGFBP1 by PL in HepG2 cells. PD98059, an ERK inhibitor, was used to test this assumption. The ERK inhibitor $(40 \mu \mathrm{M})$ effectively reduced IGFBP1 mRNA levels in the control and PL-treated cells (Fig. 4B and C). Notably, in the presence of the ERK inhibitor, there was no significant difference in IGFBP1 mRNA levels between cells with or without PL at $6 \mathrm{~h}$ (Fig. 4B). In addition, the elevated IGFBP1 protein expression by PL in the cell lysate and culture medium was entirely eradicated by the ERK inhibitor (Fig. 4D and E). Elevations in p-ERK1 and p-c-Jun protein expression by PL were eliminated by PD98059 (Fig. 4D and E). These results indicate that the ERK pathway is important in the stimulation of IGFBP1 by PL.

Inhibition of protein synthesis inhibits elevation in the expression of IGFBPI protein by $P L$. To understand the role of protein synthesis in the stimulation of IGFBP1 by PL, HepG2 cells were treated with cycloheximide for 6 or $12 \mathrm{~h}$. Cycloheximide $(2 \mu \mathrm{g} / \mathrm{ml})$ completely inhibited the elevation of IGFBP1 protein expression induced by PL (Fig. 5). These results suggest that higher expression of IGFBP1 protein by PL is dependent on protein synthesis.

\section{Discussion}

The present study demonstrated that PL elevates the expression of IGFBP1 mRNA and protein levels in HepG2 cells. Notably, IGFBP1 protein observed in the cell culture medium was also elevated by PL, indicating that a high concentration of IGFBP1 was released into the culture medium. PL was observed to cause a marked elevation in IGFBP1 mRNA, but for other B6-vitamers, including PLP, PN and PM, this effect was not observed on IGFBP1. Our previous study showed that the inhibitory effect of PL on the LPS-induced expression of iNOS and COX-2 in RAW264.7 cells was stronger compared with PLP (9). Kanouchi et al (30) showed that when RAW264.7 cells were cultured in a culture medium treated with the B6 vitamers PL, PM, PN or PLP, only PL interacted with the cell surface. PL is known as a primary form of transport in blood and is capable of freely passing through the cell membrane, while PLP cannot easily cross the cell membrane and must be hydrolyzed by alkaline phosphatase into PL (31-33). Therefore, PL appears to affect IGFBP1 expression in HepG2 cells as PL crosses cell membranes from a cultured medium.

Higher expression of IGFBP1 mRNA by PL was inhibited by PD98059, an ERK inhibitor, suggesting that the ERK pathway may be important in PL-induced IGFBP1 gene expression. Previous studies have observed that the expression of IGFBP1 may be regulated via the MAPK pathway (JNK and ERK). Inhibitors of the MAPK pathway were able to entirely eliminate IGFBP1 expression by various inducers $(27,29)$. The current results show that PL-induced IGFBP1 expression was inhibited by the ERK inhibitor. The phosphorylated c-Jun protein was also reduced by the ERK inhibitor. A previous study showed that c-Jun is required to promote the maximal expression of the IGFBP1 promoter in HepG2 cells in the presence of IL-6 (28). Phosphorylation of c-Jun by ERK in PC12 cell differentiation has been demonstrated (34). According to the present results and previous studies $(28,34)$, PL may stimulate the expression of IGFBP1 in HepG2 cells by elevating the ERK/c-Jun pathway. Since the JNK pathway is hypothesized to be involved in the stimulation of IGFBP1 gene expression in HepG2 cells (29), PL was investigated to determine whether it activates JNK in HepG2 cells. The activation of JNK by PL was not observed. Thus, the JNK pathway does not appear to be involved in PL-induced IGFBP1 expression. The current study shows that $\mathrm{PL}$ at $500 \mathrm{mM}$ significantly affects the growth of HepG2 cells between 12 and $48 \mathrm{~h}$. It is unclear whether the alteration in cell growth is associated with the modulation of IGFBP1 and ERK.

In summary, the present study provides evidence for PL stimulating IGFBP1 expression in HepG2 cells. The ERK/c-Jun pathway may be involved in the induction of IGFBP1 by PL. Vitamin B6 and IGFBP1 are hypothesized as protective factors against cancers and cardiovascular disease $(7,15,22,35)$. Thus, it is of interest to examine whether vitamin B6 intake causes a higher production of IGFBP1 in the liver, resulting in higher circulating IGFBP1, which in turn leads to lower development of these diseases.

\section{Acknowledgements}

This study was supported in part by a Grant-in-Aid for Scientific Research from the Ministry of Education, Culture, Sports, Science and Technology of Japan.

\section{References}

1. Ishihara J, Otani T, Inoue M, Iwasaki M, Sasazuki S and Tsugane S: Japan Public Health Center-based Prospective Study Group: Low intake of vitamin B-6 is associated with increased risk of colorectal cancer in Japanese men. J Nutr 137: 1808-1814, 2007.

2. Theodoratou E, Farrington SM, Tenesa A, McNeill G, Cetnarskyj R, Barnetson RA, Porteous ME, Dunlop MG and Campbell H: Dietary vitamin B6 intake and the risk of colorectal cancer. Cancer Epidemiol Biomarkers Prev 17: 171-182, 2008.

3. Larsson SC, Orsini N and Wolk A: Vitamin B6 and risk of colorectal cancer: a meta-analysis of prospective studies. JAMA 303: 1077-1083, 2010.

4. Zhang XH, Ma J, Smith-Warner SA, Lee JE and Giovannucci E: Vitamin B6 and colorectal cancer: current evidence and future directions. World J Gastroenterol 19: 1005-1010, 2013.

5. Komatsu SI, Watanabe H, Oka T, Tsuge H, Nii $\mathrm{H}$ and Kato N: Vitamin B-6-supplemented diets compared with a low vitamin B-6 diet suppress azoxymethane-induced colon tumorigenesis in mice by reducing cell proliferation. J Nutr 131: 2204-2207, 2001.

6. Komatsu S, Watanabe H, Oka T, Tsuge H and Kat N: Dietary vitamin B6 suppresses colon tumorigenesis, 8-hydroxyguanosine, 4-hydroxynonenal, and inducible nitric oxide synthase protein in azoxymethane-treated mice. J Nutr Sci Vitaminol (Tokyo) 48: 65-68, 2002

7. Komatsu S, Yanaka N, Matsubara K and Kato N: Antitumor effect of vitamin B6 and its mechanisms. Biochim Biophys Acta 1647: 127-130, 2003.

8. Kayashima T, Tanaka K, Okazaki Y, Matsubara K, Yanaka N and Kato N: Consumption of vitamin B6 reduces colonic damage and protein expression of HSP70 and $\mathrm{HO}-1$, the anti-tumor targets, in rats exposed to 1,2-dimethylhydrazine. Oncol Lett 2: 1243-1246, 2011.

9. Yanaka N, Koyama TA, Komatsu S, Nakamura E, Kanda M and Kato N: Vitamin B6 suppresses NF-kappaB activation in LPS-stimulated mouse macrophages. Int J Mol Med 16: 1071-1075, 2005.

10. Diffley JF: Affinity labeling the DNA polymerase alpha complex. I. Pyridoxal 5'-phosphate inhibition of DNA polymerase and DNA primase activities of the DNA polymerase alpha complex from Drosophila melanogaster embryos. J Biol Chem 263: 14669-14677, 1988. 
11. Matsubara K, Matsumoto H, Mizushina Y, Lee JS and Kato N: Inhibitory effect of pyridoxal 5'-phosphate on endothelial cell proliferation, replicative DNA polymerase and DNA topoisomerase. Int J Mol Med 12: 51-55, 2003.

12. Martial J,Zaldivar J,BullP, Venegas A and Valenzuela P: Inactivation of rat liver RNA polymerases I and II and yeast RNA polymerase I by pyridoxal 5'-phosphate. Evidence for the participation of lysyl residues at the active site. Biochemistry 14: 4907-4911, 1975.

13. Vermeersch JJ, Christmann-Franck S, Karabashyan LV, Fermandjian S, Mirambeau G and Der Garabedian PA: Pyridoxal 5'-phosphate inactivates DNA topoisomerase IB by modifying the lysine general acid. Nucleic Acids Res 32: 5649-5657, 2004.

14. Matsubara K, Mori M, Matsuura Y and Kato N: Pyridoxal 5 '-phosphate and pyridoxal inhibit angiogenesis in serum-free rat aortic ring assay. Int J Mol Med 8: 505-508, 2001

15. Lee PD, Giudice LC, Conover CA and Powell DR: Insulin-like growth factor binding protein-1: recent findings and new directions. Proc Soc Exp Biol Med 216: 319-357, 1997.

16. Yee D, Jackson JG, Kozelsky TW and Figueroa JA: Insulin-like growth factor binding protein 1 expression inhibits insulin-like growth factor I action in MCF-7 breast cancer cells. Cell Growth Differ 5: 73-77, 1994.

17. Van den Berg CL, Cox GN, Stroh CA, Hilsenbeck SG, Weng CN, McDermott MJ, Pratt D, Osborne CK, Coronado-Heinsohn EB and Yee D: Polyethylene glycol conjugated insulin-like growth factor binding protein-1 (IGFBP-1) inhibits growth of breast cancer in athymic mice. Eur J Cancer 33: 1108-1113, 1997.

18. Zhang $X$ and Yee $D$ : Insulin-like growth factor binding protein(IGFBP-1) inhibits breast cancer cell motility. Cancer Res 62: 4369-4375, 2002.

19. Ngo TH, Barnard RJ, Leung PS, Cohen P and Aronson WJ: Insulin-like growth factor I (IGF-I) and IGF binding protein-1 modulate prostate cancer cell growth and apoptosis: possible mediators for the effects of diet and exercise on cancer cell survival. Endocrinology 144: 2319-2324, 2003.

20. Wei EK, Ma J, Pollak MN, Rifai N, Fuchs CS, Hankinson SE and Giovannucci E: A prospective study of C-peptide, insulin-like growth factor-I, insulin-like growth factor binding protein-1, and the risk of colorectal cancer in women. Cancer Epidemiol Biomarkers Prev 14: 850-855, 2005.

21. Le Marchand L, Wang H, Rinaldi S, Kaaks R, Vogt TM, Yokochi L and Decker R: Associations of plasma C-peptide and IGFBP1 levels with risk of colorectal adenoma in a multiethnic population. Cancer Epidemiol Biomarkers Prev 19: 1471-1477, 2010.

22. Rajwani A,Ezzat V, Smith J, Yuldasheva NY,Duncan ER, Gage M, Cubbon RM, Kahn MB, Imrie H, Abbas A, Viswambharan H, Aziz A, Sukumar P, Vidal-Puig A, Sethi JK, Xuan S, Shah AM, Grant PJ, Porter KE, Kearney MT and Wheatcroft SB: Increasing circulating IGFBP1 levels improves insulin sensitivity, promotes nitric oxide production, lowers blood pressure, and protects against atherosclerosis. Diabetes 61: 915-924, 2012.
23. Taub R: Liver regeneration 4: transcriptional control of liver regeneration. FASEB J 10: 413-427, 1996.

24. Leu JI, Crissey MA, Craig LE and Taub R: Impaired hepatocyte DNA synthetic response posthepatectomy in insulin-like growth factor binding protein 1-deficient mice with defects in C/EBP beta and mitogen-activated protein kinase/extracellular signal-regulated kinase regulation. Mol Cell Biol 23: 1251-1259, 2003.

25. Ink SL and Henderson LM: Vitamin B6 metabolism. Ann Rev Nutr 4: 455-470, 1984

26. Nakari M, Kanouchi $\mathrm{H}$ and Oka T: High dose of pyridoxine induces IGFBP-3 mRNA expression in MCF-7 cells and its induction is inhibited by the 553 -specific inhibitor pifithrin- $\alpha$. J Nutr Sci Vitaminol (Tokyo) 57: 280-284, 2011.

27. Frost RA, Nystrom GJ and Lang CH: Stimulation of insulin-like growth factor binding protein-1 synthesis by interleukin-1beta: requirement of the mitogen-activated protein kinase pathway. Endocrinology 141: 3156-3164, 2000.

28. Leu JI, Crissey MA, Leu JP, Ciliberto G and Taub R: Interleukin-6-induced STAT3 and AP-1 amplify hepatocyte nuclear factor 1-mediated transactivation of hepatic genes, an adaptive response to liver injury. Mol Cell Biol 21: 414-424, 2001.

29. Magne L, Blanc E, Marchand A, Fafournoux P, Barouki R, Rouach $\mathrm{H}$ and Garlatti M: Stabilization of IGFBP1 mRNA by ethanol in hepatoma cells involves the JNK pathway. J Hepatol 47: 691-698, 2007.

30. Kanouchi H, Shibuya M, Tsukamoto S, Fujimura Y, Tachibana H, Yamada K and Oka T: Comparisons of uptake and cell surface binding among pyridoxal, pyridoxine, and pyridoxamine in RAW264.7 cells. Nutrition 26: 648-652, 2010.

31. Lumeng L, Brashear RE and Li TK: Pyridoxal 5'-phosphate in plasma: source, protein-binding, and cellular transport. J Lab Clin Med 84: 334-343, 1974.

32. Anderson BB, O'Brien H, Griffin GE and Mollin DL: Hydrolysis of pyridoxal-5'-phosphate in plasma in conditions with raised alkaline phosphate. Gut 21: 192-194, 1980.

33. Sakurai T, Asakura T, Mizuno A and Matsuda M: Absorption and metabolism of pyridoxamine in mice. I. Pyridoxal as the only form of transport in blood. J Nutr Sci Vitaminol (Tokyo) 37: 341-348, 1991.

34. Leppä S, Saffrich R, Ansorge W and Bohmann D: Differential regulation of c-Jun by ERK and JNK during PC12 cell differentiation. EMBO J 17: 4404-4413, 1998

35. Shen J, Lai CQ, Mattei J, Ordovas JM and Tucker KL: Association of vitamin B-6 status with inflammation, oxidative stress, and chronic inflammatory conditions: the Boston Puerto Rican Health Study. Am J Clin Nutr 91: 337-342, 2010 